Ali Ataullah \& Minh Hang Le 131

\title{
Comment:
}

\section{Interest and the Modern Economy: A Reply}

\section{Ali Ataullah \& Minh Hang Le*}

"No single human being, human agency or group has a right to impose its view, in matters of the faith, on others. That must be left to every individual conscience to decide for him or her ... Religious leaders and jurists, with their literalist training, often lack knowledge of societies and economies to have insights that may illuminate the fresh significance of old formulae" ${ }^{1}$.

In the previous issue of this journal, Zaman \& Zaman (2001), by criticising Hamza Alavi, imply that the implementation of the so-called Islamic Banking is in the best interest of economy and only by following this system can we be serious Muslims. According to them, this implementation could be justified on the basis of modern economic and financial theories, and also by evaluating the financial system of developed countries. This paper only briefly discusses some acute theoretical and practical shortcomings in their article and suggests that the non-interest based system $^{2}$ is not appropriate for the Pakistani economy, at least in the conceivable future.

\section{Islamic Banking and Islamisation of Zia}

As Hamza Alavi (op cit.) has rightly mentioned that Islam prohibited interest or riba, in the pre-capitalist Bedouin community under some particular circumstances modern society, however, is not facing a similar situation. Therefore, taking Qur'an only according to its literal meanings and not recognising the settings or asbab al-nuzul behind it, will lead to a static form of Islam. As far as the introduction of Islamic Banking in Pakistan is concerned, there is a general consensus that this was only an element of Zia's Islamisation process to somehow legitimise his autocratic rule by playing with people's religious sentiments (see, for example, Husain, 1999, or Zaidi, 1999)

\footnotetext{
* The authors are postgraduate research students at the Department of Economics \& Finance and the Business School, University of Durham, UK respectively. For correspondence: E-mail: L.M.Hang@durham.ac.uk

${ }^{1}$ Humza Alvi, Significance of Riba \& Interest, Dawn, Feb. 09-10,2000.

${ }^{2}$ The non-interest based system in this article refers to the so-called Islamic Banking system because the authors, like Hamza Alavi, believe that this system does not portray Islam dynamically.
} 


\section{Bank Loans in US and Japan}

Zaman \& Zaman argue "from a purely practical point of view, equity based finance is typically more common than interest-based finance in US and Japan (pp.116)". However, the phenomenon is not that simple. For example, Japan's rapid economic growth is based on the guided industrialisation in which the Ministry of Finance trivialised the role of equity markets and used interest-based banks as a channel to inject capital in industries that were considered to be an engine of economic growth (Lincoln, 1999). During the 1970s, bank loans represented 95 per cent of Japanese corporate borrowing and 67 per cent of American corporate debt ${ }^{3}$. Therefore, it is inaccurate to say that equity is a more popular way of financing in Japan and the US. Of course now the US is moving towards more equity-based financing, but that is due to the colossal development of the American equity markets as well as American industries during the last five decades ${ }^{4}$. In a developed country like the US, high education level, coupled with well-structured institutional framework and availability of better information regarding firms' activities, motivate people to invest in the equity market and there are more chances of a direct interaction between lenders and borrowers through such markets. On the other hand, in developing countries, like Pakistan, neither are the sources of information reliable nor the majority of people capable enough to evaluate the information. This, therefore, leads to an underdeveloped stock market where firms and the public (mostly middle-class) cannot rely on such markets to adjust their financial needs. In a situation where the stock market is highly underdeveloped, the introduction of the non-interest based system can lead to further deterioration of the economy.

\section{Equity Financing and Asymmetric Information}

Referring to Modigiliani and Miller (1958, 1964), Zaman \& Zaman state "... taking these complexities into account actually favours equity based financing over debt based financing for many reasons (pp.117)”. The issue of optimal capital structure is still controversial. Therefore, it is highly inappropriate to conclude that equity financing is a better way of financing ${ }^{5}$. Also the modern theories on "Optimal Contracting" suggest that an optimal

${ }^{3}$ Bank of Japan (1977, pp.23-24) and Statistical Abstract of the United States (1976, pp.477) quoted in Lincoln (1999).

${ }^{4}$ This development was partly due to well-organised debt markets during the early stages of development in the US.

${ }^{5}$ See Harris and Raviv (1991) for a comprehensive review of costs and benefits of debt and equity financing. 
contract that reduces the agency problems between lenders and borrowers of funds is more like a debt contract ${ }^{6}$.

\section{Inappropriate use of Arrow-Debreu Framework}

To defend the non-interest based system, Zaman and Zaman quote: "the ban on ... interest ... would not interfere with the efficiency of the economy" (Obstfeld and Rogoff, 1996, pp.273, footnote 5). They, however, hopefully unintentionally, neglected a key assumption behind such efficiency. We would hereby full cite the reference:

"Scholars of Islamic banking have long emphasised that the ban in the Qur'an (holy book) on riba or interest, does not rule out profit-sharing or other arrangements where the lender takes on risk. When there are complete markets for Arrow-Debreu securities, a ban on non-contingent debt contracts alone would not interfere with the efficiency of the economy." (Obstfeld and Rogoff, 1996, page 273, footnote 5)

The assumption on complete markets for Arrow-Debreu securities in fact was initiated in the classic model of Arrow (1964) and Debreu (1959). This is an extreme assumption about a market for insuring any type of risk. In this hypothesised and perfectionised market (no risk and no uncertainty), debt simply brings no more trading opportunities as people already have a full set of Arrow-Debreu claims that can be traded. Therefore, the proponents of the non-interest based system should evaluate the possibility of existence of such markets, particularly in Pakistan.

\section{Government Financing and Interest}

According to Zaman \& Zaman, due to interest-based loans the Government of Pakistan is misusing the public's funds. They, however, do not recognise that it is not the interest-based system but the very nature of our corrupt governments that is responsible for huge unutilised public debts. The interest-based system, on the other hand, has helped the rapid development of England, Germany, and France in the seventeenth and eighteenth century. Particularly in the case of England, the Bank of England utilised huge public borrowing to restore the kingdom from destruction due to nine years of war with France (North and Weingast, 1989). Even the industrialisation of Pakistan during its early periods, when the country had no capital at all, was carried out through the interestbased system (see, for example, Zaidi, 1999). The eradication of corruption

\footnotetext{
${ }^{6}$ Ibid.
} 
in the government of Pakistan cannot be carried out by abolishing the interest-based economy. More concrete steps, like nationwide education, are required for this task.

\section{Future Research on Islamic Banking}

As compared to other economic and financial issues, there has been relatively modest research on Islamic Banking. It can be argued that most of the proponents of this system are so-called Islamic bankers, who will find it very beneficial to market the idea of Islamic Banking that would lead to relatively low competition from foreign banks that have sophisticated interest-based products. Literature on the non-interest based system does not incorporate human capital $^{7}$ as a factor of production. For example, the non-interest based system cannot accommodate models like the overlappinggeneration model (Jappelli and Pagano, 1994). Let us discuss a simple case here. A young student needs funds (say 220,000 ) to finance her professional degree at a high-ranking university. The student, after finishing her degree, gets a high paid job and repays her debts. Her degree will not only help her but also help accelerate economic growth. But, in the absence of the interest-based system, will there be anyone who is willing to finance her studies by some kind of profit-loss sharing agreement? The non-interest based system, therefore, only considers physical capital as a factor of production and not the other important factor i.e. human capital.

\section{Implementation of Islamic Banking in Pakistan}

Currently some banks are providing so-called Islamic products to firms and public. But a closer look at these products shows that they are not different from conventional interest-based instruments ${ }^{8}$. If the government of Pakistan implemented so-called Islamic banking, then it might lead to a further deterioration in this already weak economy. Given the current institutional set-up in Pakistan, the implementation of Islamic Banking, would lead to scarcity of available funds because savers, due to asymmetric information, would not trust the profit-loss sharing system of banks. And if in this case, the government provides explicit or implicit guarantee to the savers, then again it will be "un-Islamic" because the savers now have a guarantee that they will not face any kind of loss. Also due to the new financial system, foreign investors will be more cautious to enter the Pakistani market.

\footnotetext{
${ }^{7}$ The new growth theories suggest that Human Capital is as important as (or even more than) physical capital in economic growth of developed and developing countries (see, for example, Romer, 1987).

${ }^{8}$ The Islamic products like Murabaha and Ijarah are effectively the same as conventional interest-based instruments.
} 


\section{Conclusion}

This paper briefly discusses the theoretical and practical shortcomings in Zaman and Zaman (2001). The paper strongly opposes the idea that equity financing is a superior method of raising funds. It, however, does not imply that debt or other interest-based methods are better. There are costs and benefits attached to both. If the financial system has to play a significant role in the process of economic development, then it requires both of these instruments i.e. equity and interest based instruments. The paper also shares the view with Hamza Alavi that interest was banned due to the exploitive nature of society in the pre-capitalist community, and the circumstances are quite different in the modern world. Interest is bad only and only if it is exploitive in nature and if there are no benefits attached to it. We, however, provided some evidence that the interest-based system helped in the early development of today's developed countries. This paper, therefore, calls for further research on the nature and operation of the noninterest based system not only by religious [scholars] but also by modern financial and economic theorists. And in designing any such system, these scholars should consider the fact that we are not living in Utopia. 
136 The Lahore Journal of Economics, Vol.6, No.2

\section{References}

Arrow, K. 1964, "The Role of Securities in the Optimal Allocation of Risk Bearing”, Review of Economic Studies (Vo1. 29), pp. 155-73.

Debreu, G. 1959, Theory of Value, New Haven, CT: Yale University Press.

Harris, M. and Raviv, A. 1991, “The Theory of Capital Structure”, Journal of Finance (Vo1. 46, Issue 1), pp. 297-355.

Husain, I. 1999, Pakistan: The Economy of an Elitist State, Oxford University Press.

Jappelli, T. and M. Pagano 1994, "Savings, Growth and Liquidity Constraints", Quarterly Journal of Economics, (Vo1. 109), pp. 83-109).

Lincoln, E.J. 1999 “Japan's Financial Problems”, Brookings Papers on Economic Activity 1998: 2, pp. 347-375.

Modigliani, F. and M. H. Miller 1958, "The Cost of Capital, Corporate Finance and the Theory of Investment”, American Economic Review (Vol. 48), pp. 261-297.

Modigliani, F. and M. H. Miller 1963, "Corporate Income Taxes and the Cost of Capital: a Correction”, American Economic Review (Vo1. 53), pp. 433-443.

North, D. and B. Weingast 1989, "Constitution and commitment: The Evaluation of Institution Governing Public Choices in Seventeenth Century England", Journal of Economic History, 49, pp. 803-32.

Obstfeld, M. and K. Rogoff 1996, Foundations of International Macroeconomics, Cambridge, Mass.: MIT Press.

Romer, P.M. 1987, "Increasing Returns and Long-Run Growth", Journal of Political Economy, (Vo1. 94, 50, pp. 1002-1037.

Zaidi, S.S. 1999, Issues in Pakistan’s Economy, Oxford University Press.

Zaman, A. and A. Zaman 2001, "Interest and the Modern Economy", The Lahore Journal of Economics, (Vo1. 6), pp. 113-128. 